\title{
Oxidative stress and the presence of bacteria increase gene expression of the antimicrobial peptide aclasin, a fungal CS $\alpha \beta$ defensin in Aspergillus clavatus
}

\author{
Gabriela Contreras ${ }^{\text {Corresp.. }}{ }^{1}$, Nessa Wang ${ }^{1}$, Holger Schäfer ${ }^{1}$, Michael Wink ${ }^{\text {Corresp. } 1}$ \\ 1 Institute of Pharmacy and Molecular Biotechnology, Ruprecht-Karls-Universität Heidelberg, Heidelberg, Baden-Württemberg, Germany \\ Corresponding Authors: Gabriela Contreras, Michael Wink \\ Email address: contreras@uni-heidelberg.de,wink@uni-heidelberg.de
}

Background. Antimicrobial peptides (AMPs) represent a broad class of naturally-occurring antimicrobial compounds. Plants, invertebrates and fungi produce various AMPs as, for example, defensins. Most of these defensins are characterised by the presence of a cysteine-stabilised $\alpha$-helical and $\beta$-sheet (CS $\alpha \beta)$ motif. The changes in gene expression of a fungal $C S \alpha \beta$ defensin by stress conditions were investigated in Aspergillus clavatus. A. clavatus produces the $\mathrm{CS} \alpha \beta$ defensin Aclasin, which is encoded by the aclasin gene.

Methods. Aclasin expression was evaluated in submerged mycelium cultures under heat shock, osmotic stress, oxidative stress and the presence of bacteria by qPCR.

Results. Aclasin expression increased 2-fold under oxidative stress conditions and in the presence of viable and heat-killed Bacillus megaterium. Under heat shock and osmotic stress, aclasin expression decreased.

Discussion. The results suggest that oxidative stress and the presence of bacteria might regulate fungal defensin expression. Moreover, fungi might recognise microorganisms as plants and animals do. 


\section{Oxidative stress and the presence of bacteria increase} 2 gene expression of the antimicrobial peptide aclasin, 3 a fungal CS $\alpha \beta$ defensin in Aspergillus clavatus

6 Gabriela Contreras ${ }^{1}$, Nessa Wang ${ }^{1}$, Holger Schäfer ${ }^{1}$, Michael Wink ${ }^{1}$

7

$8{ }^{1}$ Institute of Pharmacy and Molecular Biotechnology, Heidelberg University, Heidelberg,

9 Germany

10

11 Corresponding Author:

12 Michael Wink

13 Email address: wink@uni-heidelberg.de 


\section{Abstract}

15 Background. Antimicrobial peptides (AMPs) represent a broad class of naturally-occurring antimicrobial compounds. Plants, invertebrates and fungi produce various AMPs as, for example, defensins. Most of these defensins are characterised by the presence of a cysteine-stabilised $\alpha$ helical and $\beta$-sheet $(\mathrm{CS} \alpha \beta)$ motif. The changes in gene expression of a fungal $\mathrm{CS} \alpha \beta$ defensin by stress conditions were investigated in Aspergillus clavatus. A. clavatus produces the CS $\alpha \beta$ defensin Aclasin, which is encoded by the aclasin gene.

Methods. Aclasin expression was evaluated in submerged mycelium cultures under heat shock, osmotic stress, oxidative stress and the presence of bacteria by qPCR.

Results. Aclasin expression increased 2-fold under oxidative stress conditions and in the presence of viable and heat-killed Bacillus megaterium. Under heat shock and osmotic stress, aclasin expression decreased.

Discussion. The results suggest that oxidative stress and the presence of bacteria might regulate fungal defensin expression. Moreover, fungi might recognise microorganisms as plants and animals do.

\section{Introduction}

Antimicrobial peptides (AMPs) are a diverse group of naturally occurring molecules that are produced by a wide range of organisms, both prokaryotes and eukaryotes. AMPs are short peptides (consisting of 12 to 50 amino acids), commonly cationic and amphipathic. AMPs show a broad-spectrum activity against bacteria and other organisms, including gram-positive and gram-negative bacteria, parasites, fungi, viruses and even cancer cells (Mahlapuu et al., 2016). Additionally, AMPs are part of the innate defence mechanism in animals and plants (Heine, 2008). The role of AMPs is less understood in prokaryotes and lower eukaryotes. It has been suggested that AMPs might help them to compete for nutrients with other microorganisms

38 (Ageitos et al., 2017).

The largest group of AMPs are defensins. Defensins are cysteine-rich peptides found in many organisms throughout the eukaryotic kingdom. Vertebrate defensins contain a three-stranded antiparallel $\beta$-structure. Defensins produced by invertebrates, plants and fungi mostly contain a common structure composed of an $\alpha$-helix linked to a $\beta$-sheet by three to four disulfide bridges. This structure is called cysteine-stabilised $\alpha$-helical and $\beta$-sheet (CS $\alpha \beta)$ motif (Silva et al., 2014). Defensin genes can be differentially or constitutively expressed in plants, vertebrates and invertebrates. In these three groups of organisms, defensins are produced as host defence response to bacteria and fungi (Harder et al., 1997; Irving et al., 2001; Penninckx et al., 1996). Signalling pathways of host defence response share similarities among plants, invertebrates and vertebrates (Han et al., 1998; Ip et al., 1993; Ryals et al., 1997). For example, the receptors, which recognise pathogens, are highly conserved among these organisms (Medzhitov et al., 1997; Whitham et al., 1994). 
51 In plants, presence of pathogens and abiotic stress (salt, drought and cold) activate the plant

52

53

54

55

56

57

58

59

60

61

62

63

64

65

66

67

68

69

70

71

72

73

74

75

76

77

78

79

80

81

82

83

84

85

86

87

88

89 immune system signalling cascade whose defence response includes the expression of defensins as well as other AMPs (Campos et al., 2018; Taji et al., 2004). It has been suggested that defensins are involved in stress adaptation in addition to the antimicrobial activity (Do et al., 2004; Koike et al., 2002).

Fungi are attractive sources of antimicrobial compounds. However, only few fungal CS $\alpha \beta$ defensins have been characterised in terms of their antimicrobial activity. Some of these defensins are plectasin, copsin and eurosin, which are synthesised by Pseudoplectania nigrella, Coprinopsis cinerea and Eurotium amstelodami, respectively (Essig et al., 2014; Mygind et al., 2005; Oeemig et al., 2012). These fungal defensins have antimicrobial activity mainly against gram-positive bacteria.

Another class of defensins found in fungi is defensin with antifungal activity, also called defensin-like antifungal. The structure of defensin-like antifungals consists of five antiparallel $\beta$ sheets forming a $\beta$-barrel. The gene expression of defensin-like antifungals from Aspergillus giganteus and Aspergillus niger is altered by environmental stress conditions (Meyer \& Stahl, 2002; Meyer et al., 2002; Paege et al., 2016). For example, carbon starvation increases the expression of these defensin-like antifungals (Meyer et al., 2002; Paege et al., 2016). In Aspergillus giganteus, osmotic stress, heat shock and the presence of other fungi enhance the gene expression of antifungals (Meyer \& Stahl, 2003; Meyer et al., 2002). In Penicillium chrysogenum, limited glucose induces the expression of antifungals (Marx et al., 1995). In both cases, defensin-like antifungal genes contain putative Stress Response Element (STRE) sequences in their promoters (Marx, 2004; Meyer et al., 2002). STRE is a consensus sequence (5'-AGGGG-3' and 5'-CCCCT-3') and is present in the promoters of genes that are regulated by stress.

In silico analysis indicated the identification of eight families of putative $\operatorname{CS} \alpha \beta$ defensins from published fungal genomes (Zhu, 2008; Zhu et al., 2012). This prediction was based on the sequence similarity and the presence of the CS $\alpha \beta$ motif. Among the putative defensins described is Acasin (encoded by acasin gene), which is produced by the filamentous fungus Aspergillus clavatus (Zhu, 2008).

As mentioned previously, environmental conditions can alter the expression of plant defensins and some defensin-like antifungals from fungi. However, the transcriptional regulation of CS $\alpha \beta$ defensins is not well-understood. Stress conditions might also change the gene expression of fungal CS $\alpha \beta$ defensins, such as aclasin. Aclasin expression might be a defence response to bacterial presence. The present work aimed to investigate aclasin expression under stress conditions (heat shock, osmotic, oxidative and presence of bacteria) in submerged mycelium of Aspergillus clavatus. The present investigation demonstrates that oxidative stress and the presence of bacteria increased 2-fold aclasin expression after $30 \mathrm{~min}$ of exposure. Our findings suggest that filamentous fungi would produce $\mathrm{CS} \alpha \beta$ defensins as defence response. Moreover $A$. clavatus, as other fungi, might possess specific mechanisms of bacterial recognition. 
90

91

92

93

94

95

96

97

98

99

100

101

102

103

104

105

106

107

108

109

110

111

112

113

\section{4}

115

116

117

118

119

120

121

\section{Materials \& Methods}

\section{Strains and conditions of culture}

Aspergillus clavatus DSM 3410 and Bacillus megaterium DSM 32 were obtained from the German Collection of Microorganisms and Cell Cultures (DSMZ). A. clavatus was grown on malt extract broth (MEB; $2 \%$ malt extract, $2 \%$ glucose, $0.1 \%$ peptone) at $28{ }^{\circ} \mathrm{C}$. B. megaterium was cultured on Luria-Bertani (LB) medium ( $0.5 \%$ yeast extract, $1 \%$ tryptone, $1 \% \mathrm{NaCl})$ at 37 ${ }^{\circ} \mathrm{C}$.

For conidia production, A. clavatus was grown on MEB at $28^{\circ} \mathrm{C}$ for 5 days. Conidia were harvested by washing MEB agar plates with $5 \mathrm{ml}$ of phosphate buffered saline (PBS) containing $0.01 \%$ Tween 80 and filtered through VWR 413 filter paper (VWR, USA). For submerged cultures of $A$. clavatus, a conidia suspension was inoculated in MEB to reach a final concentration of $10^{5}$ conidia $/ \mathrm{ml}$.

\section{Biomass and glucose determination}

The biomass was determined from the vegetative mycelium of submerged A. clavatus after 12, 24, 36, 48, 72, 96 and $120 \mathrm{~h}$ of cultivation. Mycelia were filtered through VWR 413 filter paper (VWR, USA). The filter papers were washed with water and dried at $80{ }^{\circ} \mathrm{C}$ for $24 \mathrm{~h}$.

Glucose in the medium was measured after 12, 36, 48, 72, 96 and $120 \mathrm{~h}$ of cultivation. Glucose was quantified based on the combined action of glucose oxidase (GOD) and peroxidase (POD) (Barham \& Trinder, 1972). Briefly, $2 \mu 1$ of each culture was incubated with $200 \mu 1$ of GOD-POD reagent, which consists of $100 \mathrm{mM}$ potassium phosphate buffer, $\mathrm{pH}$ 7.40, $10 \mathrm{mM}$ phenol, 0.3 mM 4-aminoantipyrine (Fluka, Switzerland), $10 \mathrm{kU} / 1$ glucose oxidase (Sigma, USA) and $700 \mathrm{U} / 1$ peroxidase (Sigma, USA). Samples were incubated for $30 \mathrm{~min}$ at $37^{\circ} \mathrm{C}$. Then, the absorbance was read at $505 \mathrm{~nm}$ using a TECAN spectrophotometer (Infinite 200 PRO NanoQuant, Switzerland).

\section{Heat shock, osmotic and oxidative stress conditions}

For heat shock conditions, submerged cultures of $A$. clavatus were incubated in MEB for $17 \mathrm{~h}$ at $28^{\circ} \mathrm{C}$ and $150 \mathrm{rpm}$. Then, cultures were transferred to 37 or $47^{\circ} \mathrm{C}$. Aliquots were taken after 30 and 60 min of incubation for subsequent RNA expression analysis. For osmotic stress conditions, submerged cultures were treated with $1 \mathrm{M} \mathrm{NaCl}$ final concentration. Samples were taken after 30 min of incubation. For oxidative stress, submerged cultures were treated with 2, 5 or $10 \mathrm{mM}$ hydrogen peroxide $\left(\mathrm{H}_{2} \mathrm{O}_{2}\right)$ based on previous studies in Aspergillus ssp. (Fountain et al., 2015; Reverberi et al., 2008). Samples were taken after 30 and 60 min of incubation with $\mathrm{H}_{2} \mathrm{O}_{2}$. 


\section{Co-incubation with Bacillus megaterium}

123 B. megaterium was grown in LB medium at $37^{\circ} \mathrm{C}$ to an optical density at $600 \mathrm{~nm}$ of 2

124 (exponential phase). The bacterial suspension was concentrated and stored at $4{ }^{\circ} \mathrm{C}$ for $30 \mathrm{~min}$.

125 For heat-killed culture, it was treated at $60^{\circ} \mathrm{C}$ for $30 \mathrm{~min}$. Colony-forming units (CFU) were

126 counted for each bacterial suspension after $16 \mathrm{~h}$ of incubation on LB agar plates at $37^{\circ} \mathrm{C}$.

127 A. clavatus was grown $17 \mathrm{~h}$ at $28^{\circ} \mathrm{C}, 150 \mathrm{rpm}$. Viable $\left(10^{7} \mathrm{CFU} / \mathrm{ml}\right.$ final concentration $)$ and

128 heat-killed bacteria were inoculated in submerged culture of $A$. clavatus. Samples were taken at

$12915 \mathrm{~min}$ after inoculation for later RNA expression analysis.

\section{RNA purification, cDNA synthesis and qPCR}

131 Total RNA of three biological replicates was extracted. Mycelia were harvested by vacuum 132 filtration using a VWR 413 filter paper ( $20 \mu \mathrm{m}$ pore size, VWR, USA). Then, mycelia were

133 washed with water and immediately frozen in liquid nitrogen. Samples were kept at $-80{ }^{\circ} \mathrm{C}$ until

134 RNA purification. Mycelia were disrupted by grinding with a mortar and pestle using liquid

135 nitrogen. RNA was purified by FastGene RNA Premium Purification Kit (Nippon Genetics,

136 Japan) according to the manufacturer's instructions. RNA was treated with DNase I (Nippon

137 Genetics, Japan). The integrity of RNA checked by agarose gel electrophoresis. RNA was

138 quantified spectrophotometrically at $260 \mathrm{~nm}$. The synthesis of cDNA was performed using

139 FastGene Scriptase II cDNA Kit (Nippon Genetics, Japan), $2 \mu \mathrm{g}$ RNA and oligo (dT) according

140 to the manufacturer's protocol.

141 Quantitative real-time PCR (qPCR) was carried out in triplicate in a LightCycler 96 instrument

142 (Roche, Germany) using $100 \mathrm{ng}$ cDNA, $0.5 \mu \mathrm{M}$ each primer (Table S1) and qPCR BIO SyGreen

143 Mix Lo-ROX (PCR Biosystem, UK) in $10 \mu 1$ of total volume. The act1 gene (ACLA_095800)

144 was used as reference gene (Bohle et al., 2007; Verheecke et al., 2015). Threshold cycle $\left(C_{t}\right)$

145 determination was performed using LightCycler 96 software (Roche, Germany). Expression

146 levels were calculated according to the $2^{-\Delta \Delta \mathrm{Ct}}$ method (Schmittgen \& Livak, 2008). Results are

147 presented as the mean of three independent data. Statistical analyses were performed in

148 GraphPad Prism 5.0 (GraphPad Software, USA).

\section{In silico analysis for transcription factor binding sites}

150 The 5' untranslated region (UTR) of eight genes of fungal CS $\alpha \beta$ defensins were analysed to 151 identify putative transcription factor binding sites (TFBS) (Table S2). 1,500 bp upstream of the

152 translation start site were analysed by the Saccharomyces cerevisiae promoter database (SCPD)

153 of the Cold Springs Harbor Laboratory (http://rulai.cshl.edu/SCPD/) (Zhu \& Zhang, 1999) and

154 the TRANSFAC 6.0 database using the Patch 1.0 program (http://gene-regulation.com/cgi-

$155 \mathrm{bin} / \mathrm{pub} / \mathrm{programs} / \mathrm{patch} / \mathrm{bin} /$ patch.cgi) (Matys et al., 2006). The act1 gene (ACLA_095800) of $A$.

156 clavatus was included as negative control (GenBank accession number: NW_001517095.1;

157 Region: 176194-177694). 
158

159

160

161

162

163

164

165

166

167

168

169

170

171

172

173

174

175

176

177

178

179

180

181

182

183

184

185

186

187

188

189

190

\section{Results}

\section{Aclasin expression during vegetative mycelium growth}

The aclasin gene (ACLA_006820) encodes Aclasin, a putative CS $\alpha \beta$ defensin produced by $A$. clavatus (Zhu, 2008). Aclasin expression was detected by qPCR in different stages of the vegetative mycelium growth in submerged cultures: during exponential $(24 \mathrm{~h})$, late exponential ( $36 \mathrm{~h}$ ), early stationary (48 h) and stationary growth phase (96 h). Simultaneously, the glucose content of the culture was determined during mycelium growth. The results of the aclasin gene expression are shown in Fig. 1. Aclasin was expressed in vegetative mycelium in these four stages, and no significant differences among them were observed. Aclasin expression did not change when glucose in the medium was depleted $(96 \mathrm{~h})$. These results indicate that steady-state level of aclasin does not change under glucose depletion.

\section{Aclasin expression under stress conditions}

Submerged cultures of $A$. clavatus were subjected to heat shock, osmotic and oxidative stress. The aclasin gene expression was assessed by qPCR through the change in the mRNA level compared to the untreated culture.

Heat shock and osmotic stress decreased aclasin expression.

For heat shock conditions, A. clavatus was grown in liquid MEB medium for $17 \mathrm{~h}$ and transferred to 37 or $47^{\circ} \mathrm{C}$. Changes in the aclasin gene expression were evaluated after 30 and $60 \mathrm{~min}$; the results are presented in Fig. 2A. The aclasin gene expression showed a significant decrease compared to the untreated control after $60 \mathrm{~min}$ : 10 - and 2.8 -fold at 37 and $47^{\circ} \mathrm{C}$, respectively. In addition, $h s p 30$ (ACLA_088240) expression analysis was included as a control because $h s p 30$ is upregulated by heat shock (Seymour \& Piper, 1999). Hsp30 encodes to a heat shock-like protein (HSP-30) that is responsible for the heat shock response in fungi (Tiwari et al., 2015). Hsp 30 expression was enhanced both at 37 and $47^{\circ} \mathrm{C}$, corroborating a heat shock response at transcriptional level. The lowest expression of aclasin was observed at $37^{\circ} \mathrm{C}$ and 60 min of incubation. On the contrary, the highest expression of $h s p 30$ was observed in the same conditions.

Aclasin relative expression decreased 8 - and 3 -fold at $37^{\circ} \mathrm{C}$ and $47^{\circ} \mathrm{C}$, respectively. An increase of 9-fold in $h s p 30$ relative expression was observed at $37^{\circ} \mathrm{C}$ which suggests a stronger heat shock response at 37 than $47^{\circ} \mathrm{C}$ in $A$. clavatus.

To investigate the expression of aclasin under osmotic stress conditions, submerged cultures of A. clavatus were treated with $1 \mathrm{M} \mathrm{NaCl}$. Aclasin expression decreased 4-fold in comparison to the untreated control after $1 \mathrm{~h}$ of incubation, as shown in Fig. 2B. 
191 Oxidative stress increased aclasin expression

192 Oxidative stress conditions were generated by $\mathrm{H}_{2} \mathrm{O}_{2}$. The aclasin gene expression was evaluated 193 at $2 \mathrm{mM} \mathrm{H}_{2} \mathrm{O}_{2}$ after 30 and $60 \mathrm{~min}$ (Fig. S1). In response to oxidising conditions, fungi produce 194 different scavengers against $\mathrm{H}_{2} \mathrm{O}_{2}$, as the mycelial bifunctional catalase-peroxidase (Paris et al., 195 2003) that is encoded by the cat2 gene (ACLA_044200). The cat2 expression was assessed as a 196 control to confirm the response to oxidative stress at transcriptional level (Paris et al., 2003). A

197 significant increase in aclasin expression was observed after $30 \mathrm{~min}$ of incubation. No difference 198 in aclasin expression was observed between cultures treated with $2 \mathrm{mM} \mathrm{H}_{2} \mathrm{O}_{2}$ and non-treated 199 ones after $60 \mathrm{~min}$.

200 Submerged cultures of $A$. clavatus were treated with higher concentrations of $\mathrm{H}_{2} \mathrm{O}_{2}, 5$ or $10 \mathrm{mM}$, 201 and aclasin expression was evaluated (Fig. 2C). Aclasin expression increased 2-fold after 30 min 202 of incubation $(\mathrm{P}<0.05)$. Higher expression of the cat 2 expression was observed both at 5 and 10 $203 \mathrm{mM} \mathrm{H}_{2} \mathrm{O}_{2}$, as expected.

204 Aclasin expression under co-incubation with B. megaterium

205 To determine whether the presence of microorganisms can alter aclasin expression, A. clavatus

206 was co-incubated with the gram-positive bacterium, Bacillus megaterium. A. clavatus, after $17 \mathrm{~h}$

207 of incubation, was inoculated with a viable $\left(10^{7} \mathrm{CFU} / \mathrm{ml}\right)$ or a heat-killed $B$. megaterium

208 suspension. Bacterial suspension was heat-inactivated to prevent nutrient depletion and

209 basification of the medium due to bacterial growth (Farrell \& Finkel, 2003). The results are

210 shown in Fig. 3. The aclasin gene expression significantly increased 2 -fold $(\mathrm{P}<0.01$ and $\mathrm{P}<$

2110.05 , respectively) both in the presence of viable and heat-killed $B$. megaterium cultures.

\section{Identification of putative regulatory elements in the 5' untranslated region}

213 5' UTR of aclasin was analysed to identify putative regulatory elements. Several putative TFBSs

214 were found, including TATA box, stress response element (STRE), Yap1 response element

215 (YRE) and cAMP response element (CRE) (Fig. S2). In Aspergillus ssp., Yap1 is a

216 transcriptional activator of associated genes to oxidative stress (Hong et al., 2013). CRE is

217 recognised by transcriptional factors relating to oxidative and osmotic stress responses in

218 Aspergillus ssp. (Balázs et al., 2010; Hong et al., 2013). In addition, the 5' UTR of the other

219 seven CS $\alpha \beta$ defensins (Zhu, 2008; Zhu et al., 2012) were analysed to identify STRE, CRE and

220 YRE sequences. Putative STRE sequences were found in all of the 5' UTR analysed (Fig. S3).

221 Nevertheless, STRE is a short sequence, and it was also found in the 5' UTR of the

222 housekeeping actl gene that was included as a negative control.

\section{Discussion}

224 The transcriptional regulation of fungal CS $\alpha \beta$ defensins was an open question. Understanding 225 their transcriptional regulation could help us to comprehend the biological functions of AMPs 
226

227

228

229

230

231

232

233

234

235

236

237

238

239

240

241

242

243

244

245

246

247

248

249

250

251

252

253

254

255

256

257

258

259

260

261

262

263

264

265

and the interactions between microorganisms. Considering that the structure of $\operatorname{CS} \alpha \beta$ defensins is highly conserved, understanding their transcriptional regulation might help us to understand these functions in higher eukaryotes. Furthermore, A. clavatus (as other Aspergillus sp.) is a good model system for molecular biology studies because it grows on inexpensive, defined media and can be stored for long periods (Golduran \& Morris, 1995).

In this study, aclasin expression increased about 2-fold after treatment with $\mathrm{H}_{2} \mathrm{O}_{2}$. Oxidative stress could directly or indirectly regulate aclasin expression. Previous studies have shown that a $\mathrm{CS} \alpha \beta$ defensin is involved in oxidative stress signalling (Eigentler et al., 2012).

All 5' UTR of analysed defensin genes contained STREs sequences; however, it was also found in 5' UTR of actl. Act1 is considered a housekeeping gene, and its gene expression is stable under stressful conditions in fungi (Jacob et al., 2012). STRE is a short sequence (5 bp) and can be found randomly in 5' UTR of genes. Presence of putative STREs have been linked to gene regulation by stress in fungi without experimental data. Nevertheless, the implication of regulatory elements requires experimental analysis.

A significantly lower expression of aclasin was found at high temperatures and elevated osmolarity. In plants, an indirect down-regulation of defensin by heat shock factors has been observed (Kumar et al., 2009). This phenomenon also might occur in fungi. A possible explanation for this response is that many bacteria are not capable of surviving under high temperature and high osmolarity conditions. Filamentous fungi would not require the defensins against bacteria in these conditions.

As mentioned earlier, defensin-like antifungals are induced by glucose limitation (Marx, 2004). Moreover, the gene expression of a defensin-like antifungal, AFP, decreased under oxidative stress (Meyer et al., 2002). In contrast, the aclasin expression did not change under glucose limitation (stationary phase) in this study. Furthermore, aclasin expression was enhanced in the presence of $\mathrm{H}_{2} \mathrm{O}_{2}$. Although defensin-like antifungals and $\mathrm{CS} \alpha \beta$ defensins are AMPs, their gene expression patterns are not comparable.

The gene expression of a fungal CS $\alpha \beta$ defensin produced by Aspergillus nidulans (anisin 1 ) was associated with conidiation (asexual development) (Eigentler et al., 2012). The expression of defensin-like antifungals from fungi also relates to asexual development (Meyer \& Jung, 2018). The correlation between aclasin expression and conidiation was not the focus of this work. Invertebrate and fungal $\operatorname{Cs} \alpha \beta$ defensins share structures (CS $\alpha \beta$ motifs), mechanisms of action (Schmitt et al., 2010; Schneider et al., 2010) and have been proposed to have a common origin (Zhu, 2008). Their induction might also be similar. In this work, the presence of both viable and heat-killed B. megaterium increased aclasin expression 2-fold. In invertebrates, induction of defensins is triggered by bacterial recognition. Specifically, plants and animals recognise microbe-associated molecular patterns (MAMPs) (Nürnberger et al., 2004). Aspergillus and other fungi might detect MAMPs through physical interaction (Schroeckh et al., 2009; Svahn et al., 2014). Nevertheless, this detection mechanism has not been found in fungi.

Future research could be addressed to study aclasin expression after addition of peptidoglycan, lipoteichoic acid or other MAMPS to identify what trigger aclasin expression. Moreover, it 
266 would be attractive to study the aclasin expression under presence of fungi and gram-negative

267 bacteria. Because, both fungi and gram-negative bacteria up-regulate the gene expression of

268 defensins in the red flour beetle, although these defensins are not active against these

269 microorganisms (Tonk et al., 2015).

270 Previous studies have reported that in A. giganteus, co-cultivation with fungi induced expression

271 of a defensin-like antifungal (Meyer \& Stahl, 2003). This is the first report in which the presence

272 of bacteria can induce a fungal $\operatorname{CS} \alpha \beta$ defensin. This would suggest a prominent role as

273 antibacterial agent. We have shown previously that recombinant AfusinC (a CS $\alpha \beta$ defensin from

274 Aspergillus fumigatus), as well as other CS $\alpha \beta$ defensins, exhibit prominent antibacterial activity

275 against gram-positive bacteria (Contreras et al., 2018; Essig et al., 2014; Mygind et al., 2005).

\section{Conclusions}

277 In this work, we demonstrated that aclasin was expressed in submerged mycelia of A. clavatus.

278 The gene expression did not significantly change between 24 and $96 \mathrm{~h}$ of mycelial growth, which

279 suggests that it is constitutively expressed in mycelia. Moreover, oxidative stress and the

280 presence of bacteria slightly enhanced the aclasin mRNA expression. It would be interesting to

281 investigate the corresponding protein levels of Aclasin under these conditions. Our results

282 suggest that oxidative stress and the presence of bacteria could, directly or indirectly, regulate

283 aclasin expression. These stress conditions could also induce the gene expression of other CS $\alpha \beta$

284 defensins.

285 Acknowledgements

286 We thank Mariana Roxo for her contribution in experimental design, and Hedwig Sauer-Gürth

287 and Malak Dimirieh for their suggestions about RNA isolation.

References

289

290

291

292

293

294

295

296

297

298

299

300
Ageitos JM, Sanchez-Perez A, Calo-Mata P, and Villa TG. 2017. Antimicrobial peptides (AMPs): Ancient compounds that represent novel weapons in the fight against bacteria. Biochemical Pharmacology 133:117-138 DOI: 10.1016/j.bcp.2016.09.018.

Balázs A, Pócsi I, Hamari Z, Leiter É, Emri T, Miskei M, Oláh J, Tóth V, Hegedűs N, and Prade RA. 2010. AtfA bZIP-type transcription factor regulates oxidative and osmotic stress responses in Aspergillus nidulans. Molecular Genetics and Genomics 283:289-303 DOI: 10.1007/s00438010-0513-z.

Barham D, and Trinder P. 1972. An improved colour reagent for the determination of blood glucose by the oxidase system. Analyst 97:142-145 DOI: 10.1039/AN9729700142.

Bohle K, Jungebloud A, Göcke Y, Dalpiaz A, Cordes C, Horn H, and Hempel D. 2007. Selection of reference genes for normalisation of specific gene quantification data of Aspergillus niger.

Journal of Biotechnology 132:353-358 DOI: 10.1016/j.jbiotec.2007.08.005. 
301 Campos ML, de Souza CM, de Oliveira KBS, Dias SC, and Franco OL. 2018. The role of

302 antimicrobial peptides in plant immunity. Journal of Experimental Botany 69:4997-5011 DOI:

$303 \quad 10.1093 / \mathrm{jxb} / \mathrm{ery} 294$.

304 Contreras G, Braun MS, Schäfer H, and Wink M. 2018. Recombinant AfusinC, an anionic

305 fungal CS $\alpha \beta$ defensin from Aspergillus fumigatus, exhibits antimicrobial activity against gram-

306 positive bacteria. PloS one 13: e0205509 DOI: 10.1371/journal.pone.0205509.

307 Do HM, Lee SC, Jung HW, Sohn KH, and Hwang BK. 2004. Differential expression and in situ

308 localization of a pepper defensin (CADEF1) gene in response to pathogen infection, abiotic

309 elicitors and environmental stresses in Capsicum annuum. Plant Science 166:1297-1305 DOI:

310 10.1016/j.plantsci.2004.01.008.

311 Eigentler A, Pócsi I, and Marx F. 2012. The anisin1 gene encodes a defensin-like protein and

312 supports the fitness of Aspergillus nidulans. Archives of Microbiology 194:427-437 DOI:

313 10.1007/s00203-011-0773-y.

314 Essig A, Hofmann D, Münch D, Gayathri S, Künzler M, Kallio PT, Sahl H-G, Wider G,

315 Schneider T, and Aebi M. 2014. Copsin, a novel peptide-based fungal antibiotic interfering with

316 the peptidoglycan synthesis. Journal of Biological Chemistry 289:34953-34964 DOI:

317 10.1074/jbc.M114.599878.

318 Farrell MJ, and Finkel SE. 2003. The growth advantage in stationary-phase phenotype conferred

319 by rpoS mutations is dependent on the $\mathrm{pH}$ and nutrient environment. Journal of Bacteriology

320 185:7044-7052 DOI: 10.1128/JB.185.24.7044-7052.2003.

321 Fountain JC, Scully BT, Chen Z-Y, Gold SE, Glenn AE, Abbas HK, Lee RD, Kemerait RC, and

322 Guo B. 2015. Effects of hydrogen peroxide on different toxigenic and atoxigenic isolates of

323 Aspergillus flavus. Toxins 7:2985-2999 DOI: 10.3390/toxins7082985.

324 Golduran GH, and Morris NR. 1995. Aspergillus nidulans as a model system for cell and

325 molecular biology studies. Methods in Molecular Genetics 6:48-65 DOI: 10.1016/S1067-

326 2389(06)80006-3.

327 Han ZS, Enslen H, Hu X, Meng X, Wu IH, Barrett T, Davis RJ, and Ip YT. 1998. A conserved

328 p38 mitogen-activated protein kinase pathway regulates Drosophila immunity gene expression.

329 Molecular and Cellular Biology 18:3527-3539 DOI: 10.1128/MCB.18.6.3527.

330 Harder J, Bartels J, Christophers E, and Schröder JM. 1997. A peptide antibiotic from human

331 skin. Nature 387:861 DOI: 10.1038/43088.

332 Heine H. 2008. Innate Immunity of Plants, Animals, and Humans. Heidelberg, Germany:

333 Springer-Verlag.

334 Hong SY, Roze LV, and Linz JE. 2013. Oxidative stress-related transcription factors in the

335 regulation of secondary metabolism. Toxins 5:683-702 DOI: 10.3390/toxins5040683.

336 Ip YT, Reach M, Engstrom Y, Kadalayil L, Cai H, González-Crespo S, Tatei K, and Levine M. 337 1993. Dif, a dorsal-related gene that mediates an immune response in Drosophila. Cell 75:753-

338763 DOI: 10.1016/0092-8674(93)90495-C. 
339 Irving P, Troxler L, Heuer TS, Belvin M, Kopczynski C, Reichhart J-M, Hoffmann JA, and

340 Hetru C. 2001. A genome-wide analysis of immune responses in Drosophila. Proceedings of the

341 National Academy of Sciences 98:15119-15124 DOI: 10.1073/pnas.261573998.

342 Jacob TR, Peres NTA, Persinoti GF, Silva LG, Mazucato M, Rossi A, and Martinez-Rossi NM.

343 2012. rpb2 is a reliable reference gene for quantitative gene expression analysis in the

344 dermatophyte Trichophyton rubrum. Medical Mycology 50:368-377 DOI:

345 10.3109/13693786.2011.616230.

346 Koike M, Okamoto T, Tsuda S, and Imai R. 2002. A novel plant defensin-like gene of winter

347 wheat is specifically induced during cold acclimation. Biochemical and Biophysical Research

348 Communications 298:46-53 DOI: 10.1016/S0006-291x(02)02391-4.

349 Kumar M, Busch W, Birke H, Kemmerling B, Nürnberger T, and Schöffl F. 2009. Heat shock

350 factors $\mathrm{HsfB} 1$ and $\mathrm{HsfB} 2 \mathrm{~b}$ are involved in the regulation of Pdf1.2 expression and pathogen

351 resistance in Arabidopsis. Molecular Plant 2:152-165 DOI: 10.1093/mp/ssn095.

352 Mahlapuu M, Håkansson J, Ringstad L, and Björn C. 2016. Antimicrobial peptides: an emerging

353 category of therapeutic agents. Frontiers in Cellular and Infection Microbiology 6:194 DOI:

354 10.3389/fcimb.2016.00194.

355 Marx F. 2004. Small, basic antifungal proteins secreted from filamentous ascomycetes: a

356 comparative study regarding expression, structure, function and potential application. Applied

357 Microbiology and Biotechnology 65:133-142 DOI: 10.1007/s00253-004-1600-z.

358 Marx F, Haas H, Reindl M, Stöffler G, Lottspeich F, and Redl B. 1995. Cloning, structural

359 organization and regulation of expression of the Penicillium chrysogenum paf gene encoding an

360 abundantly secreted protein with antifungal activity. Gene 167:167-171 DOI: 10.1016/0378-

361 1119(95)00701-6.

362 Matys V, Kel-Margoulis OV, Fricke E, Liebich I, Land S, Barre-Dirrie A, Reuter I, Chekmenev

363 D, Krull M, and Hornischer K. 2006. TRANSFAC and its module TRANSCompel:

364 transcriptional gene regulation in eukaryotes. Nucleic Acids Research 34:D108-D110 DOI:

365 10.1093/nar/gkj143.

366 Medzhitov R, Preston-Hurlburt P, and Janeway Jr CA. 1997. A human homologue of the

367 Drosophila Toll protein signals activation of adaptive immunity. Nature 388:394-397 DOI:

$368 \quad 10.1038 / 41131$.

369 Meyer V, and Jung S. 2018. Antifungal peptides of the AFP family revisited: are these cannibal

370 toxins? Microorganisms 6:50 DOI: 10.3390/microorganisms6020050.

371 Meyer V, and Stahl U. 2002. New insights in the regulation of the afp gene encoding the

372 antifungal protein of Aspergillus giganteus. Current Genetics 42:36-42 DOI: 10.1007/s00294-

373 002-0324-9.

374 Meyer V, and Stahl U. 2003. The influence of co-cultivation on expression of the antifungal

375 protein in Aspergillus giganteus. Journal of Basic Microbiology 43:68-74 DOI:

$376 \quad 10.1002 /$ jobm.200390007. 
377 Meyer V, Wedde M, and Stahl U. 2002. Transcriptional regulation of the antifungal protein in 378 Aspergillus giganteus. Molecular Genetics and Genomics 266:747-757 DOI: 10.1007/s00438379 001-0609-6.

380 Mygind PH, Fischer RL, Schnorr KM, Hansen MT, Sönksen CP, Ludvigsen S, Raventós D,

381 Buskov S, Christensen B, and De Maria L. 2005. Plectasin is a peptide antibiotic with

382 therapeutic potential from a saprophytic fungus. Nature 437:975-980 DOI: 10.1038/nature04051.

383 Nürnberger T, Brunner F, Kemmerling B, and Piater L. 2004. Innate immunity in plants and

384 animals: striking similarities and obvious differences. Immunological Reviews 198:249-266 DOI:

385 10.1111/j.0105-2896.2004.0119.x.

386 Oeemig JS, Lynggaard C, Knudsen DH, Hansen FT, Nørgaard KD, Schneider T, Vad BS,

387 Sandvang DH, Nielsen LA, and Neve S. 2012. Eurocin, a new fungal defensin structure, lipid

388 binding, and its mode of action. Journal of Biological Chemistry 287:42361-42372 DOI:

389 10.1074/jbc.M112.382028.

390 Paege N, Jung S, Schäpe P, Müller-Hagen D, Ouedraogo J-P, Heiderich C, Jedamzick J, Nitsche

391 BM, van den Hondel CA, and Ram AF. 2016. A transcriptome meta-analysis proposes novel

392 biological roles for the antifungal protein AnAFP in Aspergillus niger. PloS one 11:e0165755

393 DOI: 10.1371/journal.pone.0165755.

394 Paris S, Wysong D, Debeaupuis JP, Shibuya K, Philippe B, Diamond RD, and Latgé J-P. 2003.

395 Catalases of Aspergillus fumigatus. Infection and Immunity 71:3551-3562 DOI:

396 10.1128/IAI.71.6.3551-3562.2003.

397 Penninckx IA, Eggermont K, Terras FR, Thomma B, De Samblanx GW, Buchala A, Métraux J-

398 P, Manners JM, and Broekaert WF. 1996. Pathogen-induced systemic activation of a plant

399 defensin gene in Arabidopsis follows a salicylic acid-independent pathway. The Plant Cell

400 8:2309-2323 DOI: $10.1105 /$ tpc.8.12.2309.

401 Schmitt P, Wilmes M, Pugnière M, Aumelas A, Bachère E, Sahl H-G, Schneider T, and

402 Destoumieux-Garzón D. 2010. Insight into invertebrate defensin mechanism of action: oyster

403 defensins inhibit peptidoglycan biosynthesis by binding to lipid II. Journal of Biological

404 Chemistry 285:29208-29216 DOI: 10.1074/jbc.M110.143388.

405 Schmittgen TD, and Livak KJ. 2008. Analyzing real-time PCR data by the comparative $\mathrm{C}_{\mathrm{T}}$

406 method. Nature Protocols 3:1101-1108 DOI: 10.1038/nprot.2008.73.

407 Schneider T, Kruse T, Wimmer R, Wiedemann I, Sass V, Pag U, Jansen A, Nielsen AK, Mygind

$408 \mathrm{PH}$, and Raventós DS. 2010. Plectasin, a fungal defensin, targets the bacterial cell wall precursor

409 Lipid II. Science 328:1168-1172 DOI: 10.1126/science.1185723.

410 Schroeckh V, Scherlach K, Nützmann H-W, Shelest E, Schmidt-Heck W, Schuemann J, Martin

$411 \mathrm{~K}$, Hertweck C, and Brakhage AA. 2009. Intimate bacterial-fungal interaction triggers

412 biosynthesis of archetypal polyketides in Aspergillus nidulans. Proceedings of the National

413 Academy of Sciences of the United States of America 106:14558-14563 DOI:

414 10.1073/pnas.0901870106.

415 Reverberi M, Zjalic S, Ricelli A, Punelli F, Camera E, Fabbri C, Picardo M, Fanelli C, and

416 Fabbri AA. 2008. Modulation of antioxidant defense in Aspergillus parasiticus is involved in 
417 aflatoxin biosynthesis: a role for the ApyapA gene. Eukaryotic cell 7:988-1000 DOI:

418 10.1128/EC.00228-07.

419 Ryals J, Weymann K, Lawton K, Friedrich L, Ellis D, Steiner HY, Johnson J, Delaney TP, Jesse

420 T, and Vos P. 1997. The Arabidopsis NIM1 protein shows homology to the mammalian

421 transcription factor inhibitor I kappa B. The Plant Cell 9:425-439 DOI: 10.1105/tpc.9.3.425.

422 Seymour IJ, and Piper PW. 1999. Stress induction of HSP30, the plasma membrane heat shock

423 protein gene of Saccharomyces cerevisiae, appears not to use known stress-regulated

424 transcription factors. Microbiology 145:231-239 DOI:10.1099/13500872-145-1-231.

425 Silva PM, Gonçalves S, and Santos NC. 2014. Defensins: antifungal lessons from eukaryotes.

426 Frontiers in Microbiology 5:97 DOI: 10.3389/fmicb.2014.00097.

427 Svahn KS, Göransson U, Chryssanthou E, Olsen B, Sjölin J, and Strömstedt AA. 2014. Induction

428 of gliotoxin secretion in Aspergillus fumigatus by bacteria-associated molecules. PloS one

429 9:e93685 DOI: 10.1371/journal.pone.0093685.

430 Taji T, Seki M, Satou M, Sakurai T, Kobayashi M, Ishiyama K, Narusaka Y, Narusaka M, Zhu

431 JK, and Shinozaki K. 2004. Comparative genomics in salt tolerance between Arabidopsis and

432 Arabidopsis-related halophyte salt cress using Arabidopsis microarray. Plant Physiology

433 135:1697-1709 DOI: 10.1104/pp.104.039909.

434 Tiwari S, Thakur R, and Shankar J. 2015. Role of heat-shock proteins in cellular function and in 435 the biology of fungi. Biotechnology Research International 2015:1-11 DOI:

$436 \quad 10.1155 / 2015 / 132635$.

437 Tonk M, Knorr E, Cabezas-Cruz A, Valdés JJ, Kollewe C, and Vilcinskas A. 2015. Tribolium

438 castaneum defensins are primarily active against Gram-positive bacteria. Journal of Invertebrate

439 Pathology 132:208-215 DOI: 10.1016/j.jip.2015.10.009.

440 Verheecke C, Liboz T, Anson P, Diaz R, and Mathieu F. 2015. Reduction of aflatoxin

441 production by Aspergillus flavus and Aspergillus parasiticus in interaction with Streptomyces.

442 Microbiology 161:967-972 DOI: 10.1099/mic.0.000070.

443 Whitham S, Dinesh-Kumar S, Choi D, Hehl R, Corr C, and Baker B. 1994. The product of the

444 tobacco mosaic virus resistance gene $N$ : similarity to toll and the interleukin-1 receptor. Cell

445 78:1101-1115 DOI: 10.1016/0092-8674(94)90283-6.

446 Zhu J, and Zhang MQ. 1999. SCPD: a promoter database of the yeast Saccharomyces cerevisiae.

447 Bioinformatics 15:607-611 DOI:10.1093/bioinformatics/15.7.607.

448 Zhu S. 2008. Discovery of six families of fungal defensin-like peptides provides insights into

449 origin and evolution of the CS $\alpha \beta$ defensins. Molecular Immunology 45:828-838 DOI:

$450 \quad$ 10.1016/j.molimm.2007.06.354.

451 Zhu S, Gao B, Harvey PJ, and Craik DJ. 2012. Dermatophytic defensin with antiinfective

452 potential. Proceedings of the National Academy of Sciences of the United States of America

453 109:8495-8500 DOI: 10.1073/pnas.1201263109. 


\section{Figure 1}

Relative aclasin mRNA (ACLA_006820) expression during mycelial growth in A. clavatus DSM 3410.

A. clavatus $\left(10^{5}\right.$ conidia/ml) was incubated in MEB at $28^{\circ} \mathrm{C}$ and $150 \mathrm{rpm}$. Biomass represents the mycelial dry weight. For RNA analysis, mycelia samples were collected at 24, 36, 48, and $96 \mathrm{~h}$ of incubation. Relative aclasin mRNA expression was determined by qPCR according to the $2^{-\Delta \Delta t}$ method. The act1 gene (ACLA_095800) was used as housekeeping gene. Normalised gene expression values for each time were compared with normalised gene expression at 24 $\mathrm{h}$ of incubation. Data are means and standard deviations from three independent experiments. Aclasin relative expressions were analysed by ANOVA followed by Bonferroni post-tests $(P>0.05)$. 


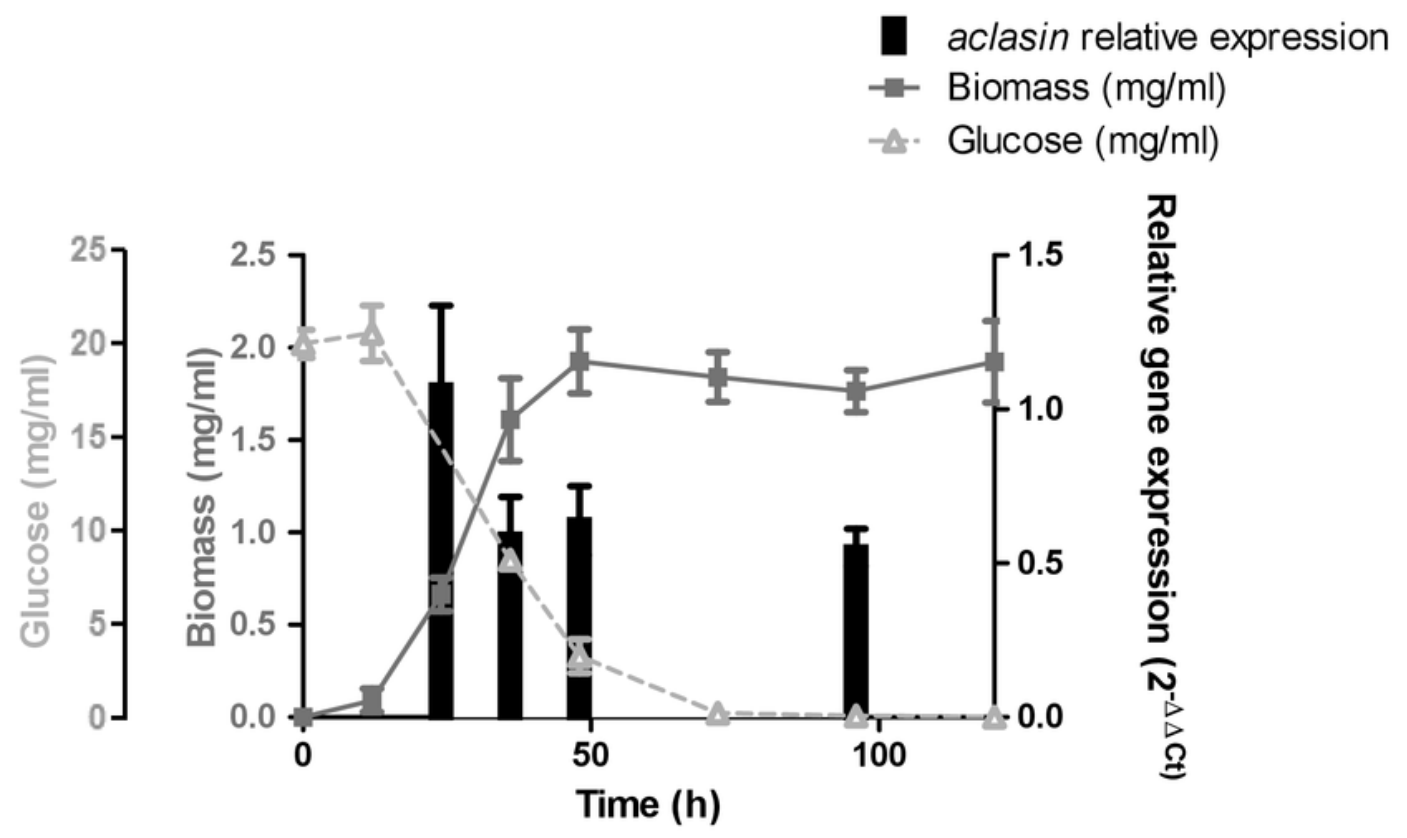




\section{Figure 2 (on next page)}

Relative aclasin gene (ACLA_006820) expression under heat shock, osmotic, and oxidative stress conditions.

Submerged cultures of $A$. clavatus were incubated for $17 \mathrm{~h}$ in MEB at $28^{\circ} \mathrm{C}$ and $150 \mathrm{rpm}$. (A) For heat shock stress, cultures were transferred to 37 or $47^{\circ} \mathrm{C}$. Aliquots were taken at 30 and 60 min. Hsp30 (ACLA_088240) was included as a positive control. (B) For osmotic stress, cultures were treated with $1 \mathrm{M} \mathrm{NaCl}$ for $1 \mathrm{~h}$. (C) For oxidative stress, cultures were treated with 5 or $10 \mathrm{mM} \mathrm{H}_{2} \mathrm{O}_{2}$ for 30 min. Cat2 gene ( ACLA_044200), which encodes a mycelial bifunctional catalase-peroxidase, was used as a positive control for a gene up-regulated by oxidative stress. Relative aclasin mRNA expression was determined by qPCR according to the $2^{-\Delta \Delta c t}$ method. The act1 gen (ACLA_095800) was used as reference gene and the untreated condition as control. Controls have a value of 1 . Data represent the mean ( \pm standard deviations) of three biological replicates. Relative expressions were analysed by ANOVA followed by Bonferroni post-tests in comparison to the control for heat shock and oxidative stress, and student t-test for the osmotic assay $(*, \mathrm{P}<0.05 ; * *, \mathrm{P}<0.01 ; * * *, \mathrm{P}<0.001)$. 
A PeerJ

Heat shock

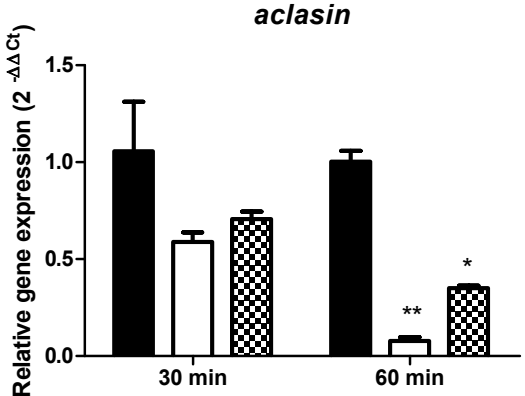

Manuscript to be reviewed

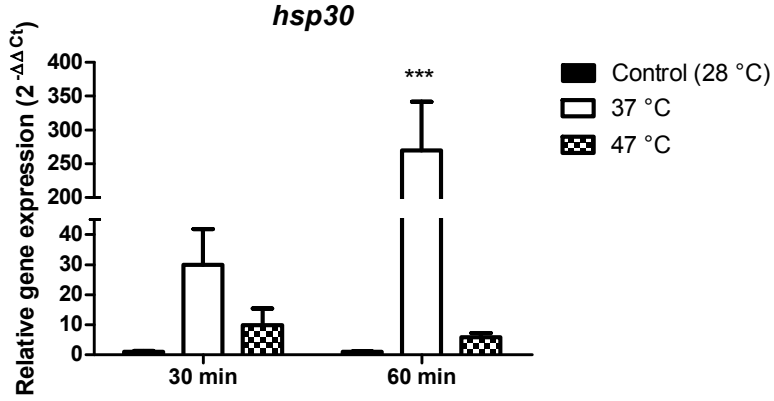

B

Osmotic stress

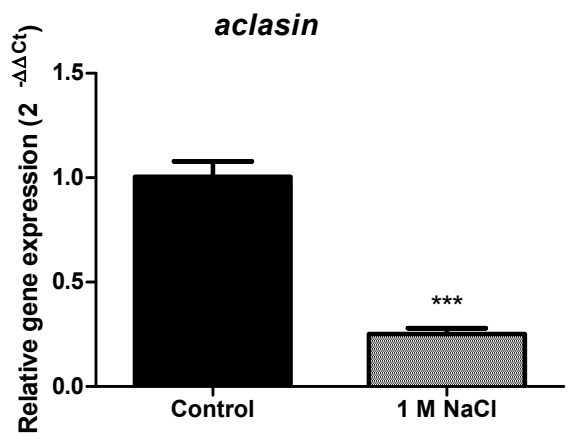

C

Oxidative stress
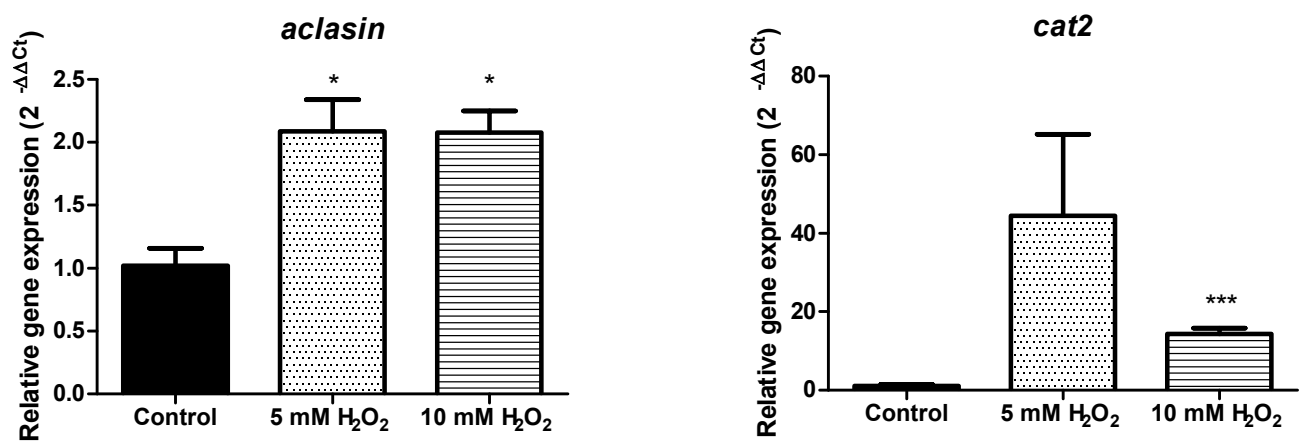


\section{Figure 3}

Relative aclasin gene (ACLA_095800) expression in A. clavatus in co-cultivation with B. megaterium.

A. clavatus was incubated $17 \mathrm{~h}$ in MEB at $28^{\circ} \mathrm{C}$ and $150 \mathrm{rpm}$. Cultures were inoculated with viable $\left(10^{7} \mathrm{CFU} / \mathrm{mL}\right)$ or heat-killed culture of $B$. megaterium. Samples were taken after $15 \mathrm{~min}$ for total RNA purification. The act1 was used as reference gene. Data represent the mean ( \pm standard deviations) of three biological replicates. The relative expressions were analyzed by ANOVA followed by Bonferroni post-tests (*, P $<0.05 ; * *, P<0.01)$. 


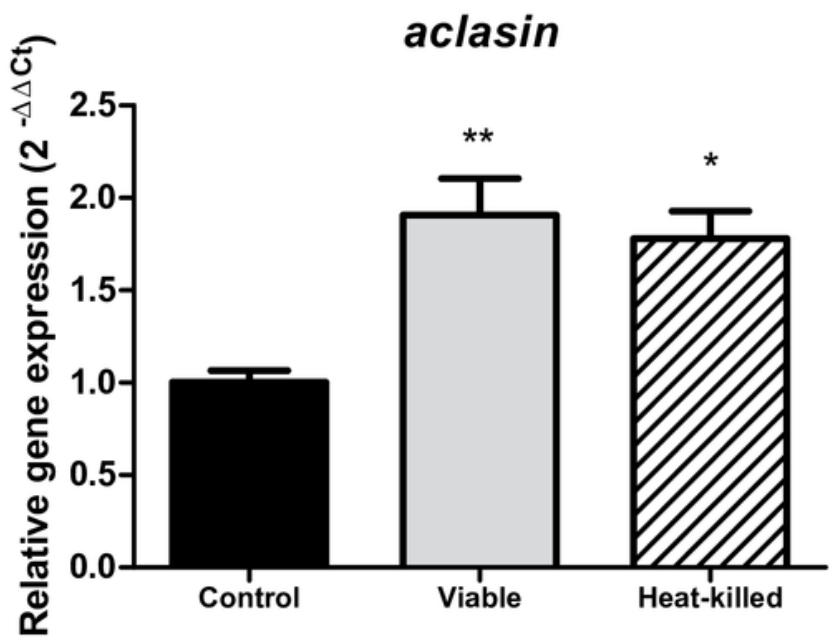

